\title{
APPLICATION OF NETWORK ANALYSIS CRASHING METHOD IN EVALUATING THE SCHEDULE OF NAVAL BASE FACILITY DEVELOPMENT PROJECT
}

\author{
Raditya Novianto ${ }^{1}$, Suparno ${ }^{2}$, Sutrisno ${ }^{3}$, Abdul Rahman ${ }^{4}$ \\ 1,3,4 Indonesian Naval Technology College, STTAL, Surabaya, Indonesia \\ 2Industrial Engineering Department, Institut Teknologi Sepuluh Nopember, Surabaya, Indonesia
}

\begin{abstract}
A project of base facility is a kind of routine developing in Indonesian Naval. In this developmentt is necessary to develop methods in measuring performance and evaluating project time through a more accurate critical path feature. The research problem statement is how to evaluate the project schedule related to the time and cost of the Indonesian Navy's facility construction project by conducting a case study as a study for project scheduling at a later stage. The research objective is to identify the critical path of the project through network analysis, determine the factors that cause delays and how to overcome them, and calculate the time effectiveness and cost-efficiency of the project based on the calculation of scheduling acceleration. In this study, project performance measurement was carried out using the Earned Value Method (EVM) and network analysis using the Precedence Diagram Method (PDM). The solution to overcome delays with the crashing project method. The results of the discussion identified 15 critical path activities. The factor causing the delay is the delay in activities on the critical path due to the low level of productivity of the workforce group. The crashing method through additional 2 hours/day overtime can solve the problem of delays so that project implementation can be accelerated from the implementation of 256 working days to 226 working days (11.72\% effectiveness) with the initial project cost of Rp. $74,316,727,585.00$ reduced to $R p .72,152,162,704.00$ (2.91\% efficiency). It will be measurable and reasonable in responsibility when it was suitable with the target.
\end{abstract}

Keywords : Network Analysis, Naval Base, and Project Development.

\section{INTRODUCTION.}

In the current time, a port is one of the important infrastructures in the maritime world which consists of land and waters around it with certain boundaries as a place of activity for government and economic activities which is used as a place for ships to dock, anchor, pick up and drop off passengers and load and load-unload cargo equipped with shipping safety facilities and port support activities as well as a place for intramodal and intermodal transport, Widyatmoko (2008). The port serves as a gateway and facilitates relations between regions, islands, or even between continents and nations. With this function, the port construction project must be accountable socially, economically, and technically.

The project is said to be successful if the goals set are achieved and meet quality standards of time and cost. In general, project planning which consists of scheduling, budgeting and quality serves as the main basis that will lead a project to success. Scheduling is one component of planning results in terms of resource performance in the form of project duration, costs, manpower, materials and equipment that can provide information about the project implementation schedule and project progress. The work implementation schedule is planned in such a way as to be carried out on time, however in practice in the field often it is not in accordance with the determined planning so the project delays often occur. Project implementers need to accelerate time as a solution to the delay. The consequence of the accelerated project time is the increase in direct costs. Therefore, a Time-Cost Trade- Off (TCTO) analysis is needed in order to obtain optimal results. Crashing is a method that can be used to accelerate projects. Crashing is a deliberate, systematic and analytic process by testing all activities in a project that are focused on critical path activities (Soeharto, 1999). This research was conducted by analyzing the crashing method and using a case study on the Indonesian Navy Jetty Construction Project in Saumlaki Phase I which experienced delays. This project is targeted for completion on September 13, 2019 , with an implementation time of 240 working days. With the acceleration, it is expected to be used as an evaluation material so that the continuation of the project for the next step can be completed on time even faster than the initial planning. Efforts to accelerate it are carried out by using the alternative of adding working hours and increasing the manpower.

Previous research that has a relationship with this problem / research was carried out by, among others, Ririh, K. R., \& Hidayah, N. Y. (2020) in a study entitled Reducing Project Duration of an Apartment Project by Waskita Karya using the 
Crashing Method. Ballesteros-Perez, P., Elamrousy, K. M., \& Gonzalez-Cruz, M. C. (2019) studied NonLinear Time-Cost Trade-Off Models of Activity Crashing: Application to Construction Scheduling and Project Compression with Fast-Tracking. Feylizadeh, M. R., Mahmoudi, A., BaghelDRour, M., \& Li, D. F. (2018) in a study entitled Project Crashing using a Fuzzy Multi-Objective Model Considering Time, Cost, Quality and Risk Under Fast Tracking Technique: A case study. Novitasari, AD, Sandora, R., \& Lestari, RL (2018) in their research entitled Project Scheduling Analysis using Presedence Diagram Method (PDM). In another title, Scheduling Project Crashing Time Using Linear Programming Approach: Case Study was researched by Chitra, K., \& Halder, P. (2017). Another study entitled Monitoring and Controlling RCC Work in Delayed Construction Projects by Gujarati, N., \& Balapgol, B. S. (2016). In this study, a network analysis in the form of the Precedent Diagram (PDM) method was carried out using the Ms Project 2016 application in order to obtain jobs on the critical path. Work that falls into the critical trajectory will be carried out by crashing calculations by adding work hours (overtime) and additional manpower. From the two alternatives to calculate the project acceleration, the final result of this research will be obtained in the form of a more efficient project time acceleration and cost.

\section{MATERIAL AND METHOD}

Project scheduling is one of the elements of planning results, which can provide information about the schedule of plans and project progress in terms of resource performance in the form of costs, manpower, equipment and materials as well as project duration plans and time progress for project completion (Husen, 2009). The precedent diagram (PDM) method is a node which is generally in the form of a rectangle, while the arrows are only a pointer to the relationship between the various activities concerned (Nurjaman, $\mathrm{K}$ et al, 2014). Time cost trade off is a deliberate, systematic and analytical process by testing all activities in a project that are focused on critical path activities (Erwianto, 2004).

\subsection{Project Costs}

a. Direct costs for the project include direct costs for manpower (wages for manpowerers, foremen, workers), materials and materials needed, and costs for the use of equipment that are closely related to project activities. Direct costs of a project are the total amount of each activity.

b. Indirect Costs, including project fixed costs which include tractor rental, diesel-electric rental, night guard / security fees, depreciation of equipments, bank interest and so on.

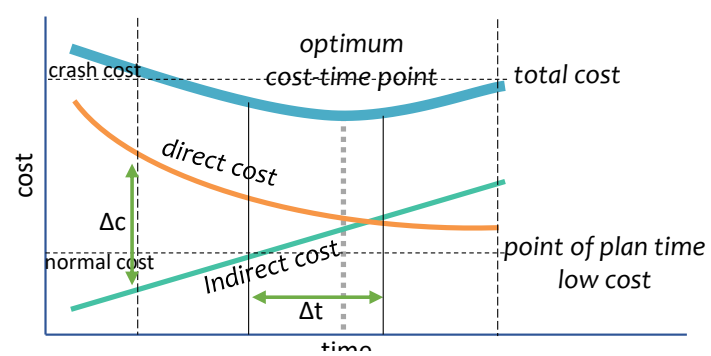

Figure 1. Graph of the Time and Cost Relationship

The method used is to review the slope of each line segment which can provide identification of the effect of costs on reducing project completion time (Nurjaman, $\mathrm{K}$ et al, 2014).

\subsection{Preparation of Network Planning with the Precedence Diagram (PDM) Method}

Precedence Diagram Method (PDM) is a network that is also known as an Activity on Node (AON) because the location of its activity is in the node section. The project schedule obtained is in the form of a block diagram, so that to make it a Network Diagram several steps must be taken to compile it, among others (Nurjaman, $\mathrm{K}$ et al, 2014):

- Identify the project scope and break it down into activity components.

- Arrange the components of activity according to the logical sequence of dependencies into a network.

- Provide an estimate of the time span for each job.

- Identification of critical paths, floats, and project completion timelines.

- Increase the efficiency and results in the use of resources.

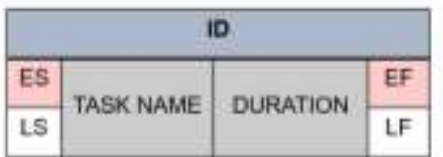

Figure 2. Node symbol of activity in PDM

\subsection{Crashing the Duration}

There are ways to accelerate the duration of activities in the project, namely (Husen, 2014):

a. Organizing work shifts.

b. Increase working hours or overtime.

c. Use tools more productively.

d. Increase the number of workers.

e. Using faster materials.

f. Using a faster construction method.

2.4. The crashing method procedure is as arranged follows (Soeharto, 1999):

- Make a network planning a series of activities

- Calculate the duration of project completion and identification of PDM

- Determine the normal cost of each activity

- Determine the accelerating cost of each activity 
- Determine the cost slope of each activity with the formula:

cost slope $=\frac{\text { crash cost }- \text { normal cost }}{\text { normal duration-crash duration }}$

- Shorten the duration of activities starting from the critical activity path with the lowest cost slope

- If a new critical path is formed during the acceleration process, it will accelerate the critical activities that have the lowest slope combination.

- Continue to reduce activity time until the point of PPC (Point of Project Crashing) or until there is no more critical path.

- Calculate and total direct and indirect costs to find total costs before reducing time.

- Comparing normal costs and acceleration costs with a percentage.

\subsection{Worker Productivity}

Productivity is defined as the ratio between output and input, or it can be said as the ratio between production output and total resources used. In a construction project, the ratio of productivity is the value measured during the construction process; which can be separated into manpower costs, material costs, methods, and tools. The success of a construction project depends on the effectiveness of resource management, and workers are one resource that is not easy to manage. The wages given really depend on the skills of each worker because each worker has their own character that is different from one another.

\subsection{Implementation of Additional Working Hours (Overtime)}

One strategy to speed up the project completion time is to increase the work hours (overtime) of the workers. The addition of working hours (overtime) is very often done because it can empower existing resources in the field and simply by streamlining the additional costs incurred by the contractor. The normal working time for workers on this project is 8 hours (starting at 08.00 and ending at 17.00 with one hour of rest), then overtime hours are carried out after normal working hours are finished.

Additional working hours (overtime) can be done by adding 1 hour, 2 hours, 3 hours, and 4 hours according to the desired addition time. The greater the addition of overtime hours can cause a decrease in productivity, an indication of the decrease in worker productivity towards the additional working hours (overtime) can be seen in Figure 3. This study uses the assumption of 1 hour of overtime per day.

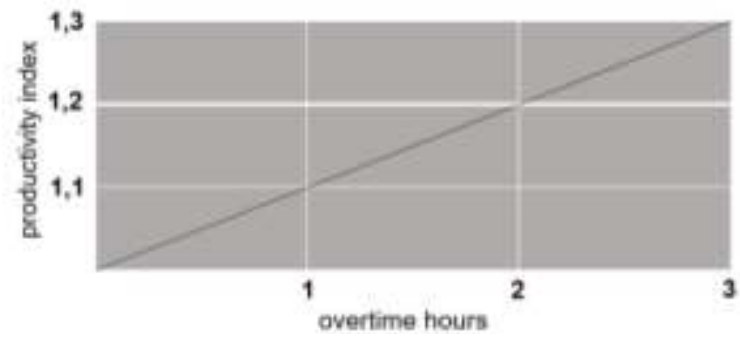

\section{Indication}

From the description above, it can be written as follows:

$$
\begin{aligned}
\text { - Daily productivity } \\
=\frac{\text { volume }}{\text { normal duration }}
\end{aligned}
$$

- Hourly productivity

$$
=\frac{\text { daily productivity }}{\text { hours of work a day }}
$$

- Daily productivity after a crash

$=$ (Hours of work per day $\times$ Hourly productivity $)+(a \times b \times$ Hourly productivity)

With:

$\mathrm{a}=$ duration of additional working hours (overtime)

$b=$ productivity reduction coefficient due to additional working hours (overtime)

- $\frac{\begin{array}{c}\text { Crash duration } \\ \text { volume }\end{array}}{\text { daily productivity after crash }}$

\subsection{Additional Worker Costs (Crash Cost)}

The additional working time will increase the cost for manpower from the normal cost of manpower. Based on the Decree of the Minister of Manpower and Transmigration of the Republic of Indonesia Number KEP. 102 / MEN / VI / 2004 that wages for additional work vary. In the addition of the first hour of work, the worker gets an additional wage of 1.5 times the normal hourly wage and in the next additional working hour, the worker will get 2 times the normal hourly wage.

The calculation for additional manpower costs can be formulated as follows:

- Normal manpower costs per day = Daily productivity $\times$ Unit price for workers' wages (6)

- Normal hourly manpower costs

$=$ Hourly productivity $\times$ Unit price for workers wages

- Overtime costs for workers

$=1,5 \times$ the normal hour's wages for the first additional (overtime) hours worked $+2 \times n \times$ the normal hour's wages for the next additional hour of work (overtime)

With :

$\mathrm{n}=$ the number of additional hours worked (overtime)

- Crash costs of workers per day $=$ (Hours of work per day $\times$ Normal manpower cost $)+(n \times$ Hourly overtime cost)

\subsection{Additional Manpower}

The increase in the number of workers will affect the efficiency of the project if it is planned realistically and takes into account several factors, namely the capacity of the job location, the ease and flexibility to do work, supervision of the manpower, and job security. The productivity of additional manpower can be calculated by the following formula: 
Crashing productivity $=($ Normal daily productivity $\mathrm{x}$ Number of accelerated workers) / (Number of normal workers) (10)

This study uses the assumption of an additional manpower of $25 \%$ of the normal manpower considering the area of the project being undertaken.

\subsection{Research methods}

The data needed in this study are secondary data. In this study, the secondary data required is in the form of project documents, namely the S curve, details of the cost budget, work volume, list of wages, and the number of workers. After the required data is collected, the crashing process is then carried out. The acceleration process in this study is carried out by emphasizing the duration of activities on the critical path with additional treatment, namely the addition of working hours and additional manpower. After knowing the activities that are on the critical trajectory, then calculating the cost slope. Crashing is performed on activities with the lowest cost slope. The crashing process is repeated several times until it reaches saturation point.

\section{RESULT AND DISCUSSION.}

\subsection{General Project Data}

Project name : The Indonesian Navy Jetty

Construction in Saumlaki (Phase I).

Project owner : Indonesian Navy

Contractor : X (Ltd)

Budget : IDR.79,367,378,000.00 (including 10\% tax)

Time of execution : 240 working days

Start date of work : :17 January 2019

Delay

\subsection{Critical Path}

Based on data processing with the Ms Project 2016 application, the following critical path are obtained:

Table 1. Critical Path

\begin{tabular}{|c|c|c|c|c|}
\hline No & Task Name & Normal & ID & Predecessot \\
\hline & & Duration & & \\
\hline 1 & Steel Pile $670 \mathrm{~cm} \mathrm{t} 16 \mathrm{~mm}$ & 42 & 5.1 & $1.65 S+53$ days \\
\hline 2 & Erection fee & 42 & 5.2 & $5.253+33 \%$ \\
\hline 3 & Pile peel \& cut off & 42 & 5.5 & 5.258 \\
\hline 4 & Pile filling concrete & 105 & 5.6 & $55 S 5+50 \%$ \\
\hline 5 & Single pile cap concrete & 119 & 5.9 & $51: 56 s s+7 \%$ \\
\hline 6 & Longitudinal beam $40770, \mathrm{~K}-350$ & 119 & 5.10 & $5159: 59$ \\
\hline 7 & Transverse beam $40 / 70, \mathrm{~K}-350$. & 119 & 5.11 & 5.10 \\
\hline 8 & Platform concrete $\mathrm{K}-350$ & 119 & 5.12 & $5.11 S S+10 \%$ \\
\hline 9 & Drainage pipe dia $3^{*}$ & 119 & 5.13 & 5.12 \\
\hline 10 & Cansteen + Ducting concrete & 119 & 5. 14 & $5.13+6 \%$ \\
\hline 11 & Solar cell lighting lamp & 14 & 5.17 & 5.14FF \\
\hline
\end{tabular}

The data above are activities that will be accelerated. Some reasons for selecting activity items in these critical activities are:

a. The selected critical activity has a resousce work or has workers so that it can be crashed.

b. In selected critical activities, acceleration can be done by adding overtime hours or by increasing the number of workers. If an additional manpower is carried out in other critical activities, the number of workers will not increase because these critical activities only have a small manpower index.

\subsection{Calculation of Crash Duration and Crash Cost With The Overtime Method}

Table 2. Overtime crashing calculations at First Itteration

\begin{tabular}{|c|c|c|c|c|c|c|c|}
\hline No. & 10 & Tack Name & $\begin{array}{c}\text { Norme } \\
\text { Duration (Dn) } \\
\text { (days) }\end{array}$ & $\begin{array}{c}\text { Nomal Cost } \\
\text { (Cn) } \\
\text { (DR) }\end{array}$ & $\begin{array}{l}\text { Crash Duration } \\
\text { (Dc) } \\
\text { (daya) }\end{array}$ & $\begin{array}{l}\text { Crash Cost } \\
\text { (Cc) } \\
\text { (IDR) }\end{array}$ & $\begin{array}{c}\text { Cont slops } \\
\text { (Cc-Cny)(Dn-De } \\
\text { (IDR) }\end{array}$ \\
\hline 1 & 5.1 & Steel Pie $070 \mathrm{~cm}+16 \mathrm{~mm}$ & 42 & 26.460000 & 38 & 25428.750 & 492188 \\
\hline 2 & 5.2 & Erection fee & 42 & 743.820 .000 & 30 & 799.163 .750 & 13.838838 \\
\hline 3 & 5.5 & Pile pool \& cut off & 42 & 70.560000 & 38 & 75.810 .000 & 1312500 \\
\hline 4 & 5.6 & Pile fling concreve & 105 & 192.300 .000 & 94 & 140.647 .500 & $75 a .864$ \\
\hline 5 & 5.9 & Single ple tap concrete & 118 & 257.040 .000 & 107 & 274.455 .000 & 1.451 .250 \\
\hline 6 & 5.10 & Lorptutinal seam 46770, K-350 & 110 & 276.090000 & 107 & 294.785000 & 1.558750 \\
\hline 7 & 5.11 & Tranwerse beden $40170, \mathrm{~K}-350$ & 119 & 188,020000 & 107 & 200.758 .750 & 1061.563 \\
\hline 8 & 5.12 & Pluctorm cenerete K-350 & 119 & $345.100,000$ & 107 & 368.481 .250 & 1.948438 \\
\hline 9 & 5.13 & Drainage pipe die 5 & 119 & 80.920000 & 107 & 86.402 .500 & 456875 \\
\hline 10 & 5.14 & Cansteen + Ducting concrete & 119 & 133280000 & 107 & 142310000 & 752500 \\
\hline 11 & 8.17 & Solar cal ightng lamp & 14 & $7,140,000$ & 13 & 7873.125 & 733.125 \\
\hline & & Total & & 2.260 .720 .000 & & 2.419 .115 .625 & \\
\hline
\end{tabular}

In the first iteration, the results obtained from the acceleration of time to 227 days at a direct cost of IDR. 2,419,115,625.00. The calculation is continued with the second iteration of the new critical path because it has not reached PPC (Point of Project Crashing).

Table 3. Overtime crashing calculations at Second Itteration

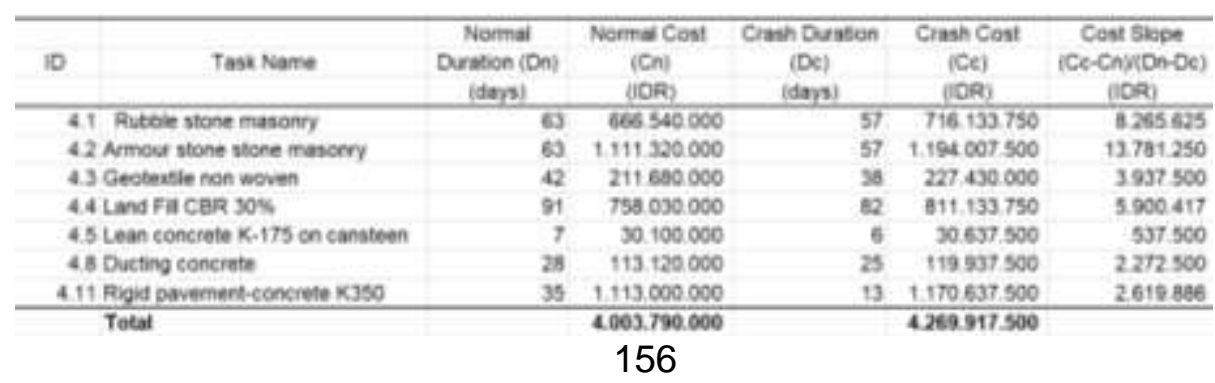


The second iteration is carried out on activities 4.5, 4.8 and 4.11. The result of this iteration is that the time acceleration becomes 222 (has reached the Point of Project Crashing) with a direct cost of IDR. 4,269,917,500.00.

\subsection{Calculation of Crash Duration and Crash Cost With The Method of Additional Manpower}

In the first iteration, the results obtained from the acceleration of time to 233 with a direct cost of IDR. 2,486,400,000.00 according to table 4 .

Table 4. Additional manpower crashing calculations at First Itteration

\begin{tabular}{|c|c|c|c|c|c|c|c|}
\hline & \multirow{3}{*}{10} & \multirow{3}{*}{ Task Name } & \multirow{3}{*}{$\begin{array}{l}\text { Nocral } \\
\text { Duration (Dn) } \\
\text { (days) }\end{array}$} & \multirow{3}{*}{$\begin{array}{c}\text { Namal Cost } \\
\text { (Ca) } \\
\text { (Rp) }\end{array}$} & \multirow{3}{*}{$\begin{array}{c}\text { Crash Duration } \\
\text { (De) } \\
\text { (days) }\end{array}$} & \multirow{3}{*}{$\begin{array}{c}\text { Crash Cost } \\
\text { (Cs) } \\
\text { (Rg) }\end{array}$} & \multirow{3}{*}{$\begin{array}{c}\text { Cost Slope } \\
\text { (Co-Cnyi(Dn-De) }\end{array}$} \\
\hline \multirow[t]{2}{*}{ No. } & & & & & & & \\
\hline & & & & & & & \\
\hline 1 & 5.1 & Steel Ple $070 \mathrm{~cm} t 16 \mathrm{~mm}$ & 42 & 26.460 .000 & 34 & 31.220 .000 & 585.000 \\
\hline 2 & 52 & Erection fee & 42 & 743.820 .000 & 34 & 898.520 .000 & 19.397500 \\
\hline 3 & 5.5 & Pile peel $\mathbf{3}$ cut off & 42 & 70.560 .000 & 34 & 80.080 .000 & 1.190 .000 \\
\hline 4 & 5.6 & Pile filing concrete & 105 & 132300.000 & 93 & 145320.000 & 1.085 .000 \\
\hline 5 & 5.9 & Single ple cap consrete & 119 & 257.040 .000 & 105 & 286.440 .000 & 2.100000 \\
\hline 6 & 5.10 & Longludina beam 4070, K-350 & 119 & 276.000 .000 & 106 & 305.480 .000 & 2100000 \\
\hline 7 & 5.11 & Transverse beam $40 / 70, \mathrm{~K}-350$. & 119 & 168.020 .000 & 108 & 203.140 .000 & 1.374 .545 \\
\hline B & 5.12 & Platform concrete K-350 & 119 & $345,100,000$ & 103 & 388.360 .000 & 2.703 .750 \\
\hline 9 & 5.14 & Cansteen + Ducting concrete & 119 & 133.280 .000 & 104 & 147.840 .000 & 970.667 \\
\hline & & Total & & 2.172 .660 .000 & & 2.486 .400 .000 & \\
\hline
\end{tabular}

Then the second iteration is continued to the new critical path because it has not reached the
Point of Project Crashing with the results according to table 5 .

Table 5. Additional manpower crashing calculations at Second Itteration

\begin{tabular}{|c|c|c|c|c|c|c|c|}
\hline & & & Normal & Normal Cost & Crash Duration & Crash Cost & Cost Slope \\
\hline \multirow[t]{2}{*}{ No. } & ID & Task Name & Duration (Dn) & $(\mathrm{Cn})$ & (Dc) & (Cc) & (Cc-Cny)(Dn-Dc) \\
\hline & & & (days) & (IDR) & (days) & (IDR) & \\
\hline 1 & 4.5 & Lean concrete K-175 on cansteen & 7,00 & 30.100 .000 & 6 & 36.220 .000 & $6,120.000$ \\
\hline 2 & 4.8 & Ducting concrete & 28,00 & $113,120.000$ & 23 & $136.580,000$ & 4.692 .000 \\
\hline \multirow[t]{2}{*}{3} & 4.11 & Rigid pavement-concrete $\mathrm{K} 350$ & 35 & 1.113 .000 .000 & 28 & 1.344 .280 .000 & 33.040 .000 \\
\hline & & Total & & 1.256 .220 .000 & & $1.517 .080,000$ & \\
\hline
\end{tabular}

The second iteration is carried out on activities 4.5, 4.8 and 4.11. The result of this iteration is the time acceleration to 221 (has reached the Point of Project Crashing) with the required cost of IDR. $1,517,080,000.00$.

\subsection{Indirect Project Costs}

Costs in a project consist of direct costs and indirect costs. Direct costs are costs for everything that will become a permanent component of the final project outcome. Determination of indirect costs based on the results of the project data obtained by the percentage for indirect costs of $2 \%$ of the total project value in detail, the calculation is as shown below:

Indirect Cost $=2 \% \times$ IDR. $72,152,162,704.00=$ IDR. $1,443,043,254.00$

Indirect Cost / day = Indirect Cost / Normal Project Duration $=$ IDR. $1,443,043,254.00 / 240$ days $=$ IDR. $6,012,680.00 /$ day

\subsection{Project Cost and Time Analysis}

Based on the analysis and calculation of the project time and costs, the results are in the following table 6 . The results of the cost and time calculations can be displayed in a cost and time relationship graph as follows figure 4 :

Table 6. Time and cost analvsis

\begin{tabular}{|c|c|c|c|c|}
\hline & Normal & Real & Over time & Addition of Manpower \\
\hline Duration (days) & 240 & 258 & 222 & 221 \\
\hline Crast Duration (days) & & & 18 & 19 \\
\hline Direct Cost (IOR) & 64.936 .946 .434 & 64.936 .946 .434 & 65.361 .469 .559 & 65.511 .546 .434 \\
\hline indirect Cost (ODR) & 1.443 .043 .254 & 1.551 .271 .498 & 1.334 .815 .010 & 1.328 .602 .330 \\
\hline Indirect Costiday (DD) & 6.012 .680 & 6.012680 & 6.012680 & 6.012 .680 \\
\hline Total Cost & 66.379 .989 .688 & 66.488 .217 .932 & $66,696.284 .569$ & 66.840 .348 .763 \\
\hline Penalty (1/1000 per day) & & 1.428 .612 .804 & & \\
\hline & 66.379 .989 .688 & 67.916 .830 .736 & 66.696 .284 .569 & 66.840 .348 .763 \\
\hline
\end{tabular}



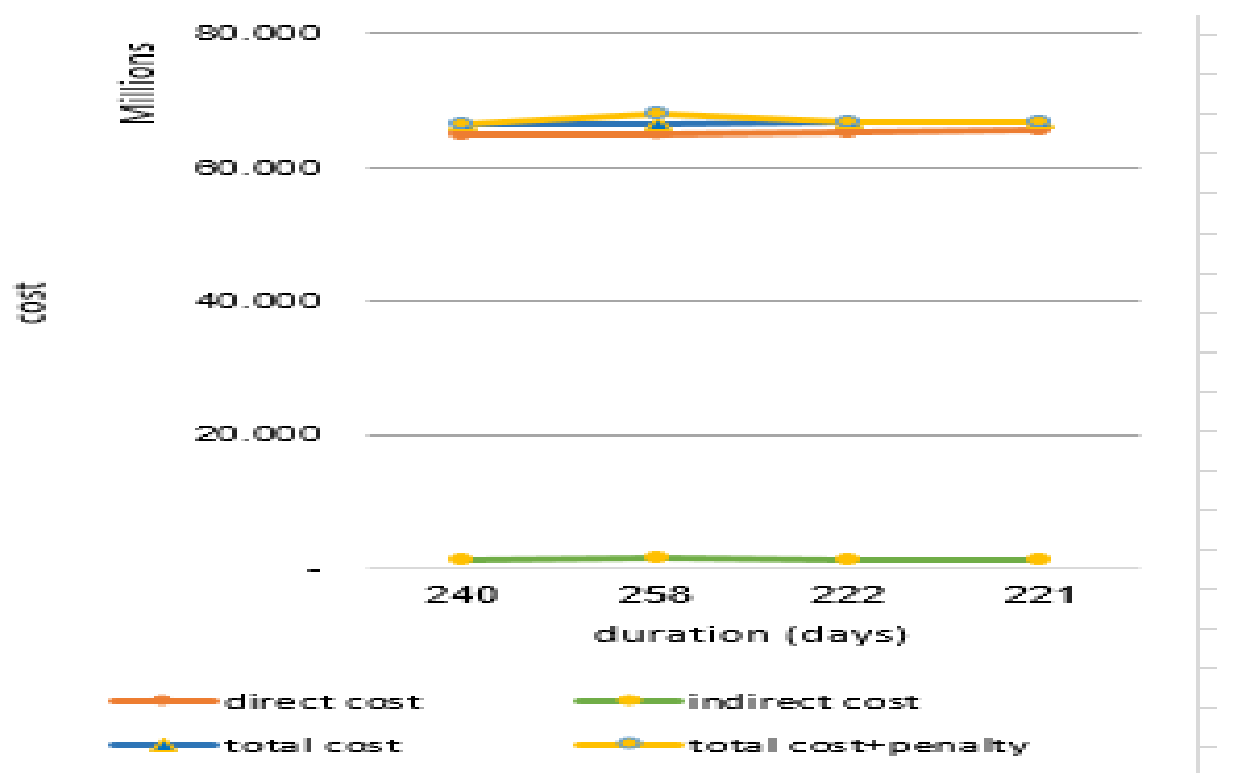

Figure 4. Graph of time and cost comparation

Furthermore, from the analysis results obtained the calculation of each project duration according to table 7 .

Table 7. Recapitulation of Duration Project Analysis.

\begin{tabular}{|c|c|c|c|c|c|}
\hline \multirow[t]{2}{*}{ Project } & \multicolumn{4}{|c|}{ Duration (days) } & \\
\hline & Plan & Real & Cras! & (day: & \\
\hline Realization & 240 & 258 & & -18 & Delay \\
\hline Overtime & 240 & 240 & 222 & 0 & Not Delay \\
\hline Additional Manpower & 240 & 239 & 221 & 1 & Not Delay \\
\hline
\end{tabular}

\section{CONCLUSIONS.}

The real duration of project implementation is 258 days from the planned 240 days at a cost of IDR.66,379,989,688.00 from the planned cost of IDR.66,379,989,688.00. After crashing with the overtime alternative, the project duration is 240 days at a cost of IDR. 66,696,284,569.00 (efficiency $1.8 \%)$. In the alternative of adding manpower, the duration after crashing is 239 days at a cost of IDR.66,840,348,763.00 (efficiency 1.61\%). So that in this study it was found that the alternative of working overtime was more efficient than the alternative of additional manpower.

\section{ACKNOWLEDGEMENTS}

The authors greatly the Support from Indonesia Naval Technology College (STTAL) for providing the necessary resources to carry out this research work.

\section{REFERENCE}

Ballesteros-Perez, P., Elamrousy, K. M., \& González-Cruz, M. C. (2019). Non-Linear
Time-Cost Trade-Off Models of Activity Crashing: Application to Construction Scheduling and Project Compression with Fast-Tracking.Automation in Construction, 97, 229-240.

Decree of the Minister of Manpower and Transmigration of the Republic of Indonesia Number 102 of 2004 concerning Overtime Time and Overtime Wages, June 25, 2004.

Ervianto, W. 2004, Construction Project Management Theory and Applications. Yogyakarta : Andi

Feylizadeh, M. R., Mahmoudi, A., BaghelDRour, M., \& Li, D. F. (2018). Project Crashing using a Fuzzy Multi-Objective Model Considering Time, Cost, Quality and Risk Under Fast Tracking Technique: A Case Study. Journal of Intelligent \& Fuzzy Systems, 35(3), 36153631.

Gujarati, N., \& Balapgol, B. S. (2016). Monitoring and Controlling RCC Work in Delayed Construction Projects. International Research Journal of Engineering and Technology (IRJET) Volume: 03 Issue: 05, 2999-3003

Husen, Abrar. (2011), Project Managemet, Yogyakarta : Andi.

Novitasari, A. D., Sandora, R., \& Lestari, R. L. (2018). Project Scheduling Analysis using Presedence Diagram Method (PDM). Journal 
of Engineering and Management in Industrial System, 6(1), 36-45.

Nurjaman, K. dan Dimyati, H. 2014, Project Management, Bandung: Pustaka Setia

Ririh, K. R., \& Hidayah, N. Y. (2020). Reducing Project Duration of An Apartment Project by Waskita Karya using Crashing Method. In IOP Conference Series: Materials Science and Engineering (Vol. 852, No. 1, p. 012087). IOP Publishing.

Soeharto, Iman. (1999), Project Management: From Conceptual To Operational (Volume 1), Jakarta: Erlangga.

Widyatmoko, Y, ( 2008), Time Acceleration Analysis Using the Crashing Method in Erection Activities at the Port 115 Tanjung Priok Project with the PERTMaster Program Application. Undergraduate Thesis, Civil Engineering University of Indonesia. Jakarta. 